Revue musicale OICRM

\title{
Remote Control: Collaborative Scoring and the Question of Authorship
}

\section{Nicholas Kmet}

Volume 5, numéro 2, 2018

Création musicale et sonore dans les blockbusters de Remote Control

URI : https://id.erudit.org/iderudit/1054145ar

DOI : https://doi.org/10.7202/1054145ar

Aller au sommaire du numéro

\section{Éditeur(s)}

Observatoire interdisciplinaire de création et recherche en musique (OICRM)

ISSN

2368-7061 (numérique)

Découvrir la revue

Citer cet article

Kmet, N. (2018). Remote Control: Collaborative Scoring and the Question of Authorship. Revue musicale OICRM, 5(2), 1-14.

https://doi.org/10.7202/1054145ar
Résumé de l'article

L’aspect le plus intéressant et le plus controversé des Remote Control Productions de Hans Zimmer est peut-être le processus créateur collaboratif grâce auquel sont produites la plupart des partitions du studio de Santa Monica. Alors que Zimmer et son associé, Steven Kofsky, se sont démenés en entretien pour mettre l'accent sur l'indépendance des compositeurs oeuvrant au studio de Santa Monica - Kofsky a déclaré que « ces compositeurs sont indépendants, ont leur propre entreprise et décrochent leurs propres films " -, la réalité dépeint une collaboration fréquente. Le site web de la maison mère du studio - une société commune à Zimmer, Kofsky et Lorne Balfe - annonce que " les clients ont accès à plus d'une douzaine de compositeurs et de monteurs musique », la collaboration entre compositeurs est clairement un argument de vente majeur pour la compagnie de Zimmer.

Une contrepartie importante de ce processus est qu'il est souvent devenu difficile, voire impossible, pour les chercheurs et les passionnés de musique de déterminer la paternité des cues individuels au sein des partitions. Il n'est pas rare qu'un groupe comprenant jusqu'à cinq compositeurs - où figurent certains des noms les plus importants du studio - soit crédité comme compositeurs de musiques supplémentaires ou remplissant d'autres rôles dans le département musique. Cet article examine le processus de collaboration mis en oeuvre au studio Remote Control Productions de Zimmer et étudie comment il remet en cause les notions traditionnelles d'auctorialité et de paternité en lien avec les partitions de musiques de film hollywoodiennes.
Ce document est protégé par la loi sur le droit d'auteur. L'utilisation des services d'Érudit (y compris la reproduction) est assujettie à sa politique d'utilisation que vous pouvez consulter en ligne.

https://apropos.erudit.org/fr/usagers/politique-dutilisation/ 


\title{
Remote Control: Collaborative Scoring and the Question of Authorship \\ Nicholas Kmet
}

\begin{abstract}
Perhaps the most interesting - and controversial - aspect of Hans Zimmer's Remote Control Productions is the collaborative workflow that many of the film scores that pass through the Santa Monica studio are produced under. While Zimmer and business partner Steven Kofsky have taken great pains in interviews to emphasize the independence of composers working at the Santa Monica studio - Kofsky has said that "these composers are independent, have their own businesses, and secure their own movies" - the reality is one of frequent collaboration. The website for the studio's parent company - a joint venture between Zimmer, Kofsky, and Lorne Balfe - advertises that "clients have access to over a dozen composers and music editors;" composer collaboration is clearly a prime selling point of Zimmer's business.

An important side-effect of this process is that it has often become difficult - if not impossible - for scholars and enthusiasts to determine the authorship of individual cues within scores. It is not uncommon for as many as five composers - including some of the more prominent names at the studio - to be credited as providing additional music or filling other roles in the music department. This article examines the collaborative process practiced at Zimmer's Remote Control Productions, and how it challenges traditional notions of authorship in relation to the Hollywood film score.
\end{abstract}

Keywords: collaboration; authorship; workflow; Remote Control.

\section{Résumé}

L'aspect le plus intéressant et le plus controversé des Remote Control Productions de Hans Zimmer est peut-être le processus créateur collaboratif grâce auquel sont produites la plupart des partitions du studio de Santa Monica. Alors que Zimmer et son associé, Steven Kofsky, se sont démenés en entretien pour mettre l'accent sur l'indépendance des compositeurs œuvrant au studio de Santa Monica - Kofsky a déclaré que "ces compositeurs sont indépendants, ont leur propre entreprise et décrochent leurs propres films »-, la réalité dépeint une collaboration fréquente. Le site web de la maison mère du studio - une société commune à Zimmer, Kofsky et Lorne Balfe - annonce que "les clients ont accès à plus d'une douzaine de compositeurs et de monteurs musique ", la collaboration entre compositeurs est clairement un argument de vente majeur pour la compagnie de Zimmer.

Une contrepartie importante de ce processus est qu'il est souvent devenu difficile, voire impossible, pour les chercheurs et les passionnés de musique de déterminer la paternité des cues individuels au sein des partitions. Il n'est pas rare qu'un groupe 
comprenant jusqu'à cinq compositeurs - où figurent certains des noms les plus importants du studio - soit crédité comme compositeurs de musiques supplémentaires ou remplissant d'autres rôles dans le département musique. Cet article examine le processus de collaboration mis en œuvre au studio Remote Control Productions de Zimmer et étudie comment il remet en cause les notions traditionnelles d'auctorialité et de paternité en lien avec les partitions de musiques de film hollywoodiennes.

Mots clés : collaboration ; auctorialité ; processus créateur ; Remote Control.

Hans Zimmer is almost certainly the most important composer working today in Hollywood, particularly in his ability to drive prevailing trends in style; in a 2007 interview, Zimmer recounted a conversation with Harry Gregson-Williams: "Harry said to me, 'Do you know, in the summer, if you look at the box office, four out of the top five films were done by people from here?"' (Hurwitz 2007). For better or for worse, this outsized influence has remained constant over the intervening decade, and the sustained success of composers writing from Zimmer's studio in Santa Monica - Remote Control Productions ${ }^{1}$ - demonstrates his dominance in the industry. This dominance has not come without controversy, however. Zimmer has at times been personally criticized for crafting unmemorable scores filled with recycled chord progressions and lackluster melodies (Macaulay 2013), and for cultivating an aesthetic of "corporate classicism" reminiscent of "McDonalds or Starbucks colonizing the world's high streets and displacing local variety with generic conformity" in the products of his colleagues at RCP (Reyland 2015, p. 122).

In an unusual twist, many of these criticisms are aimed at Zimmer's workflow and studio environment - a topic rarely discussed in relation to composers. This is generally because of Zimmer's predilection for a collaborative environment, in which numerous other composers, orchestrators, music editors, and engineers contribute materially to his scores - a fact Zimmer readily admits. It is these criticisms I find particularly interesting, because they seem steeped in the notion that the composer should be the sole creator of the music and in the misconception that Zimmer is nothing but a delegator. Similarly, the material facts of how Zimmer works and how RCP actually functions are often misrepresented or misunderstood. As a result, Zimmer is often treated to a level of hostility rarely seen directed at other composers, a fact no doubt helped by his willingness to discuss these issues. This article thus seeks to elucidate Zimmer's collaborative process, before discussing the issues that arise from his particular system - namely, questions of authorship.

\section{Remote Control Productions and Zimmer’s Collaborative Workflow}

RCP has been adopted as a shorthand for the sprawling complex that Zimmer launched in the mid 1990s as Media Ventures when Mark Mancina suggested that

1 Henceforth referred to as "RCP". 
they share space. Said Zimmer: "I wanted to build one room for me, and Mark, who's a friend, said, 'Wouldn't it be nice if we could share space or something?' It made it cheaper, but, at the same time, it seemed like a nice idea to have a sort of collaborative facility" (Hurwitz 2007). In reality, Remote Control Productions is merely Zimmer's personal loan-out company, while the entire complex is owned and operated by a joint venture between Zimmer, Lorne Balfe, and Steven Kofsky $-14^{\text {th }}$ Street Music (Kofsky 2016). With nearly 50,000 square feet of space, the facilities include composer suites, recording studios, and mixing facilities. At least 15 other composers rent space at the facility, and Kofsky stresses that they "are independent, have their own business and secure their own movies." The vast majority of the staff there do not work for Zimmer (Burlingame 2014). And yet, as much as Kofsky emphasizes the independence of the composers working from the Santa Monica facility, it seems clear that this isn't quite the case; the $14^{\text {th }}$ Street Music website, for example, notes that "clients have access to over a dozen composers and music editors who have been behind the scores to some of Hollywood's biggest blockbusters" (Anonymous 2016). So how exactly does the studio function on a day-to-day basis?

Kofsky has described the environment as "gently competitive" and having "amazing creative synergy," (Burlingame 2014) a sentiment that Zimmer has echoed:

The other day, Harry [Gregson-Williams] was mixing something, and after hearing it I just went straight back to my room and threw my stuff away and started again. We are competitive and there is a challenge, on an aesthetic level, which is really great. I heard his piece, and thought, "Hang on a second - I better live up to that" (Hurwitz 2007).

According to Zimmer, it is routine for composers to check out each other's work, offer suggestions, and help solve problems:

It's the exchange of ideas. It's other people helping to make your ideas better. Or if there is a momentary pause when you can't think of something, or you don't have the answer and you know that somebody can come and help you out. You have to be careful that you don't dilute the specificity of your original idea, and everybody who comes on board serves that idea. And if the idea is good enough, everybody will be heading in the same direction (Clarke 2009).

This sense of collaboration is crucial to the workings of RCP and remains a point of emphasis in Zimmer's own scoring process. Critics have accused Zimmer of delegating much of his music writing to assistants, only to claim credit for their original work; in reality, his process is more nuanced. Zimmer typically begins his scoring process by crafting a 20-minute suite containing the thematic content for the entire film. After approval from the director, he applies this material to sequences throughout the film (Hurwitz 2007). At this point, additional composers are brought in to flesh out and expand upon Zimmer's draft cues, in a process that some might consider arranging:

"Hans gives you a road map of the cue," explains composer Henry Jackman. "He's written a 2:30 piano piece, with loads of key changes, the mood of the movement. So you've pretty much got all the ammunition, emotionally." Jackman will lock the cue exactly to picture and begin applying Zimmer's music to the scene... Once completed, 
he can begin orchestrating the cue, with Zimmer dropping in every so often throughout the day to make sure Jackman's work maintains his original ideas (ibid. $)^{2}$.

Sometimes, Zimmer will have composers create more foundational material that he can utilize in crafting the musical soundscape for a film. Michael Levine, who worked as a composer at RCP for five years, describes an assignment from Zimmer in preparation for scoring The Dark Knight (Nolan, 2008):

Long before we had footage of the film, Hans asked Heitor Pereira (guitar), Martin Tillman (cello), and me (violin and tenor violin) to separately record some variations on a set of instructions involving 2 notes, $\mathrm{C}$ and $\mathrm{D}$. This involved a fair amount of interpretation! We each spent a week making hundreds of snippets. Then we had to listen to each other's work and re-interpret that. The end result was a toolbox of sounds that provided Hans with the attitude of his score (Levine 2013).

Zimmer is hardly stingy with screen credit, either; since 1990, Zimmer has worked on more than 35 films in which he shares the title credit with at least one other composer, with hundreds of additional music credits given to numerous other composers for contributing to his scores over the same timeframe. And that's without mentioning cue sheet credit, which determines royalty payments (and is thus typically most valuable to composers) and is rarely made publicly available; and yet, from the unofficial cue sheets that have leaked online, Zimmer seems to be appropriately generous $^{3}$. The score for The Dark Knight was even originally ruled ineligible by the Academy of Motion Picture Arts and Sciences for the Oscars because it credited too many people on the cue sheets - including a music editor, sound designer, and arranger (Clarke 2009).

Zimmer's most recent film with a shared title-credit, Blade Runner 2049(co-composed with Benjamin Wallfisch), necessitated an active collaborator as Zimmer was in the midst of his live tour:

The night before Zimmer left on his tour, the four of them watched the film at Zimmer's space in his Santa Monica-based Remote Control Productions. As they watched the movie, Zimmer was compelled to try out a chord progression on his keyboard. It ended up becoming a theme that would guide the score. Wallfisch then took the keys to the Blade Runner Jeep as Zimmer headed out on the road. "I said, 'Ben, you're on.' I came back in the middle of my tour, I was supposed to have ten days off," he says. "I've never worked harder than I did in those ten days" (Lobenfeld 2017).

Such open collaboration is particularly unusual within the industry, particularly Zimmer's willingness to acknowledge the value he finds in the other members of the music department: "I don't see the recording engineer as being separate from

2 It should be noted that Henry Jackman has never been credited as an orchestrator for any of Zimmer's films; he has always received additional music credits. The distinction between an orchestrator and additional music credit for Zimmer's projects is thus not entirely clear from this quote alone.

3 Unofficial cue sheets for many of Zimmer's films can be found on the fan website hans-zimmer.com. 
the musicians. They can't do what they do in isolation; we're all part of the team" (Hurwitz 2007). This, in many ways, reflects on Zimmer's unusual take on what it means to be a composer:

You have to realize that my definition of a composer isn't quite as clear-cut as other people's definition of a composer. I always get a little bit worried when people think of me as a "grand composer", because I just see myself more as a musician who likes writing music, working away on whatever, and working with other people who, through their interpretation of the notes, very often change the feeling of my notes. I see them as just as valuable as people who are a "grand composer" (Clarke 2009).

Certainly, there are practical reasons for Zimmer to collaborate with so many other composers and music department staff so closely. Zimmer is often hired for extremely large projects, often with very short deadlines, an issue that Levine notes in his discussion of his experiences while working on Rango (Verbinski 2011):

The reason he uses an army of people is that he needs them to keep up with the demands of the directors and the studios. Halfway through Rango, Gore Verbinski suddenly changed direction, threw almost everything out, and we started over. Without a team to carry out the new directions, we'd have been dead (Levine 2013).

Having a large team affords Zimmer the ability to quickly change direction with the music if the production requires it - a state of affairs that often results in the composer being replaced outright, a possibility Zimmer is generally thus able to shield himself from. Similarly, Zimmer is often able to work on significantly more projects in a calendar year than many of his contemporaries. It is interesting to note that while many film composers do not work with a large stable of collaborators as Zimmer does, television composers often do - typically because the shorter turnaround necessitates it. However, there are other considerations in determining why Zimmer favors a collaborative process and environment, and understanding them requires an examination of his entry into film music.

Zimmer's career in film music began in 1980 in the London studio of British composer Stanley Myers, after a decade of programming synthesizers for bands like the Buggles and Krisma. Myers favored a collaborative approach to film music, and much like Zimmer would years later, was unusually willing to share credit with his colleagues (Clarke 2009); Zimmer received co-composer credit with Myers on nine films, beginning with Success is the Best Revenge (Skolimowski) in 1984. It was during this time that Zimmer developed his signature sound, as well as his penchant for collaborative workflows. He would eventually model RCP after his experiences working under Myers' wing (Clarke 2009). Zimmer describes his experience with Myers as importantly formative, and it's clear from interviews how much it likely shaped his views on working in Hollywood:

In an apprenticeship, when you are in the room with the people who are making the movie, the problem is still unsolved, and you are part of the process to get to the solution. And Stanley really threw me into that. So in a funny way that might not have been a strictly formal education, but it was a really good education. I did it for four or five years. It wasn't technically an apprenticeship because I got credit on the first film we did together (Zimmer, quoted in Cassidy 2008). 
It is this experience that Zimmer seeks to replicate in his own studio-for himself, and his colleagues. For him, the benefits of the collaborative environment are twofold: he is able to compose according to a method of his own prescription in a way that allows greater speed and efficiency, while also affording him the ability to offer a similar experience to his colleagues as he experienced working with Myers.

\section{THE IsSue OF Authorship}

As beneficial as the collaborative environment remains for Zimmer, it does cause problems for both scholars and film score enthusiasts alike. As Reyland notes, "Zimmer often works on a score with many other composers; sometimes, his colleagues seem to do the majority of the composing, with Zimmer acting as a producer - practices the nuances of which are not always captured in crediting hierarchies" (Reyland 2015, p. 121). The degree of freedom that Zimmer's collaborative environment offers him does not fit into traditional models of authorship concerning film music, where roles are considerably more strictly defined - the composer writes the tunes, the orchestrator expands them for the prescribed instrumentation, the mixer balances the constituent components of the recorded music, and so on. In the RCP environment, these responsibilities are less strictly apportioned, the roles less delineated. As one reporter puts it, "If Zimmer's demotic, rather than academic, approach to film scoring has proved controversial because it challenges the conventional authorship of film composers, it has also enabled him to achieve an enviable freedom and influence" (Clarke 2009).

This has been further complicated by Zimmer's shifting role within the industry and at RCP; he is not merely a composer, but rather a producer and purveyor of film scoring talent. When Zimmer moved from the Gorfaine-Schwartz Agency to wME in 2011, it seemed inevitable that much of the talent at RCP would follow suit; one agent described him as a "king-maker" within film music. An anonymous film music veteran said that "WME is getting into the Hans Zimmer business," arguing that at the larger agency of WME, Zimmer would be able to expand his business portfolio into areas outside of film, such as TV and video games (Cassidy 2011). In 2014, Zimmer launched Bleeding Fingers Music, a TV-focused offshoot of RCP housed within the same Santa Monica complex. Composers employed there have since scored such shows as Blue Planet II and Planet Earth II, all under Zimmer's close supervision (Burlingame 2014). It seems as though Zimmer has long sought a more executive role; he has ostensibly been the head of film music for DreamWorks since 1996, though the extent to what that means exactly remains unclear - other than his scoring of practically every animated film produced by DreamWorks Animation since then.

Zimmer has relished his ability to pass work along to his understudies, providing them with stepping stones to their own, separate careers. John Powell, an RCP alum, received his first job when Zimmer was too busy to see to the score himself:

That was a gig that came into Media Ventures and they wanted Hans. They didn't want anyone else, they wanted Hans. But Hans couldn't. I'd been working with Hans at the time and he liked me and he gave them a guarantee, saying let this kid write some themes. So I did for about two weeks based on a whole load of footage and on a Friday afternoon I played the music to the editor, the producers and [the director]. I played them these demos and the editor was questioning whether or not 
Hans had written the tunes. He hadn't, although he had given me a lot of advice along the way. And they agreed to let me do it with Hans producing (Powell, quoted in Wilson 2017).

As Macaulay argues, Zimmer has crafted a collaborative system "that has much in common with the studios of the old masters, Zimmer's assistants and trainees often graduating to their own careers" (Macaulay 2013). In recent years, Zimmer frequently finds himself in the role of "score producer," or "executive music producer," or for the many TV shows that now pass through his sprawling facility, the composer of a television show's title theme only, the remaining underscore left to other composers in his employ. To what degree Zimmer exerts influence over the music from these positions is almost never clear, especially when he's producing scores for composers who have long since graduated from assistant positions. It becomes very easy to raise questions about who is responsible for what music, especially when thematic or harmonic material is recycled between scores. This is, perhaps, the most valid criticism levied at Zimmer. It remains undeniable that an RCP "sound" does exist and is a direct byproduct of Zimmer's personal style 4 . That so many of Zimmer's colleagues adopt this style is likely as much a byproduct of working with and for Zimmer as it is an expectation of the producers and directors that hire them when their first choice - Zimmer - is unavailable due to other commitments. A likely contributing factor is that working at the RCP facility guarantees access to Zimmer's proprietary sample libraries (Burlingame 2014), the significant use of which is possibly responsible for the notion that many of scores produced at the facility "sound the same." These factors have led many to an obvious question: is Zimmer dictating musical decisions for these projects where he is not a composer, or does he simply lend his reputation and assurances to younger composers dealing with skittish studios?

Perhaps no better example for just how the workflow of RCP can lead to complex questions of authorship exists than Pirates of the Caribbean: The Curse of the Black Pearl (Verbinski 2003). Officially Klaus Badelt is the composer of record, with eight other composers receiving additional music credits $^{5}$, eight orchestrators $^{6}$, five music editors ${ }^{7}$, and two music programmers ${ }^{8}$. In addition, Zimmer is credited as a music editor, music programmer, score producer, and soundtrack producer ${ }^{9}$. The reality of the situation, however, is a bit more complicated, and interviews with Zimmer in

4 For a comprehensive (and excellent) discussion of Zimmer's contemporary aesthetic, see Lehman 2016.

5 Ramin Djawadi, Jim Dooley, Craig Eastman, Nick Glennie-Smith, Steve Jablonsky, James McKee Smith, Blake Neely, and Geoff Zanelli.

6 Bruce Fowler (Supervising), Robert Elhai, Elizabeth Finch, Bill Liston, Ladd McIntosh, Yvonne S. Moriarty, Conrad Pope, and Brad Warnaar.

7 Christopher Brooks (Supervising), Kenneth Karman, Melissa Mulk (Apprentice), Daniel Pinder (Assistant), and Jeanette Surga. In addition, there are two separate music editors with credits for working on the temp score; however, they would not have been involved with Zimmer's team.

8 Rob Williams and Bart Hendrickson.s

9 These credits are according to the public IMDB page for the film. In addition to these official credits, Trevor Morris is listed as an uncredited additional music contributor. 
the years since make it clear he was far more involved with the score than publicly stated at the time. When producer Jerry Bruckheimer approached Zimmer to score the film after firing Alan Silvestri, Zimmer was nominally unavailable, busy working on Edward Zwick's The Last Samurai (2003):

I absolutely promised both Tom Cruise and Ed Zwick that I wasn't going to moonlight on anything else, and when I made the promise, I really, really believed it! But then Gore got into a little bit of trouble and I said to him, "I can't score this movie, there's no way I can, but my friend Klaus [Badelt] probably can" (Zimmer, quoted in Goldwasser 2006).

Badelt was a relatively recent addition to RCP, having quickly risen through the ranks with his work on Gladiator (Scott 2000), K-19: The Widowmaker (Bigelow 2002), and The Time Machine (Wells 2002) (Clemmensen 2011). He was, in essence, the next man up at the studio. Zimmer, however, was unable to stay entirely away, and ended up writing a significant portion of the thematic material found throughout the film:

Klaus is a wonderful composer, but I couldn't help myself from writing many of the tunes, and then I sort of orchestrated the way those tunes would sound as well, setting the tone. Klaus wrote some more tunes and with our tunes wrote the score, and Blake Neely, Geoff Zanelli, and everyone else went at it (Zimmer, quoted in Goldwasser 2006).

According to Zimmer, he is responsible for roughly $90 \%$ of the thematic material found within the film score, the majority of it written in a single night (Schweiger 2011). Because the score was a replacement score, the deadline for completion was exceptionally tight, and as a result, most of the RCP staff was brought on to help. According to Geoff Zanelli, it was "all hands on deck" (Zanelli). The degree to which each composer contributed to the score is difficult to determine, for several reasons. As Christian Clemmensen's critical review notes, "You can hear pieces of music in the contents of this work that remind of a few of the individual composers credited, but without detailed cue sheets for the score, then how is anybody to know who is responsible for the very few bright spots of the composition?" (Clemmensen 2011). Zimmer's generous crediting habits similarly raise questions, as Zimmer himself has noted:

If I play you the demo for the themes of the first Pirates, it's an incredible demo where everything that is Pirates, including the orchestration, is there. It takes me a long time, but in a funny way it's more important that I spend the time doing that instead of writing the transition between one scene and the other that uses the same tune. But if someone writes that transition using my theme, or even just cuts and pastes it in the computer, I think he's done more than just hang around because I like the way things are very collaborative. And Klaus and the other composers did a lot more than write transitions in [The Curse of the Black Pearl], so I've probably ruined the credit of what "additional music" is supposed to mean, but I've done it very much on purpose (Zimmer, quoted in Goldwasser 2006).

It's just not entirely clear what level of involvement is necessary in Zimmer's mind to receive an additional music credit, though it seems to be less than what tradition would dictate. Without Zimmer's public acknowledgement of his direct involvement 
with the score, there would have been very little reason to assume anything other than what the official credits suggest. As Dan Goldwasser noted in a 2006 interview with Zimmer, many fans were confused by Badelt's absence from the series' subsequent films (Goldwasser 2006) ${ }^{10}$. And any confusion is only further compounded upon listening to the score, because many of the themes used throughout the film are highly similar to thematic material found in prior scores by Zimmer and other RCP personnel (video excerpt $1^{11}$ ).

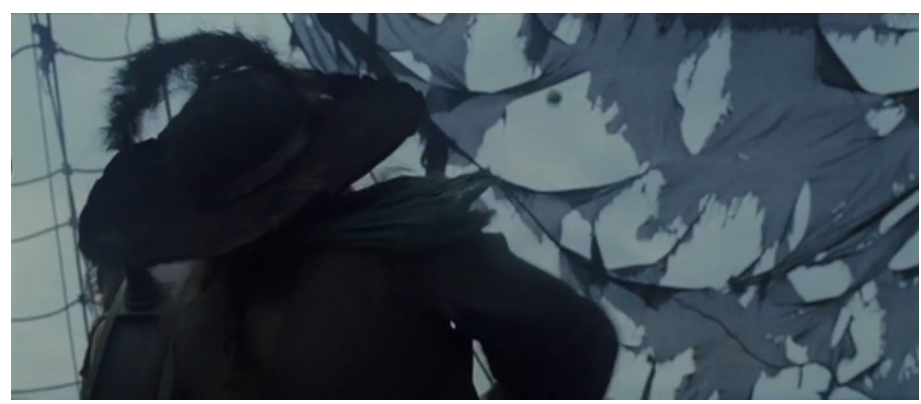

Video Excerpt 1: Gore Verbinski, Pirates of the Caribbean: The Curse of the Black Pearl, 2003 (C) Walt Disney Pictures; Michael Bay, The Rock, 1996 C Buena Vista Pictures; Ridley Scott,

Gladiator, 2000 C DreamWorks Pictures; Ridley Scott, Black Hawk Down, 2001

(C) Columbia Pictures; John Badham, Drop Zone 1994 (C) Paramount Pictures.

Determining authorship for many musical elements of The Curse of the Black Pearl is thus extremely difficult for anyone without firsthand knowledge of how the score was assembled, and almost entirely the result of Zimmer's scoring process at RCP. Even with access to the cue sheets, it is not guaranteed that authorship could be determined; the unofficial cue credits listed on the Hans Zimmer fan site list Zimmer and Badelt on every cue, even when other composers are credited as well. It is almost certain that the official cue sheet would handle its credits similarly, as composers typically only share cue sheet credit with those receiving additional music credits, as opposed to granting sole credit to the additional contributor. Even when Zimmer or his collaborators are more forthcoming about their contributions, determining authorship is tricky; Zanelli's website includes four tracks from the film that he contributed to on his website, but he notes that he "did a lot of writing on this film, much more than I can present here" (Zanelli 2017). Zanelli describes one of the cues included, "He's a Pirate," as a collaboration with Hans Zimmer: "There's an interview online somewhere in which Hans played the original demo of this piece. From there, it was placed in my hands and this is the result" (ibid.). Even with direct knowledge that Zanelli contributed to a specific cue, determining the extent of that contribution is impossible without hearing Zimmer's demo as well. Essentially, even with access to the cue sheets, analyzing any Zimmer score in an attempt to isolate the contributions

10 As Zimmer notes in that interview, Badelt's absence from the sequel scores is entirely a function of the fact that he did not work on them at all. However, he is credited with "Themes By" for Dead Man's Chest, but not for any of the later films.

11 The music volume for each excerpt has been artificially increased. 
of his colleagues is impossible without materials and knowledge available only to those within the production itself. At best we are able to say who contributed to a cue; determining the extent of that contribution is most likely next to impossible in most cases.

These issues are not isolated to individual film scores either; it's not uncommon to hear thematic material in one score by an RCP composer appear in the score of an entirely different RCP composer, without any real indication of who is actually responsible for its creation (video excerpt $2^{12}$ ).

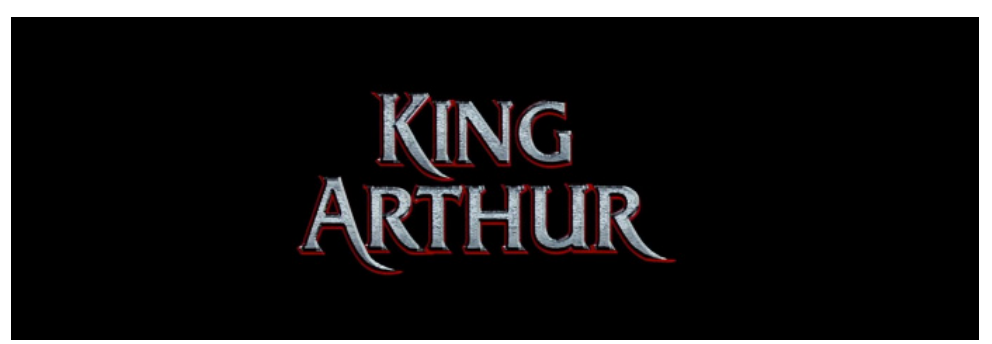

Video Excerpt 2: Antoine Fuqua, King Arthur, 2004 @ Buena Vista Pictures; Gore Verbinski, Pirates of the Caribbean: At World's End, 2007 (C) Walt Disney Pictures; Gore Verbinski, Pirates of the Caribbean: Dead Man's Chest, 2006 (C) Walt Disney Pictures; Michael Bay, Transformers, 2007 (C) DreamWorks Pictures; Christopher Nolan, Batman Begins, 2005 (C) Warner Bros. Pictures.

Often times, the official music department personnel between those scores includes no obvious overlap, making it essentially impossible to determine creative responsibility, especially since there does not appear to be an epidemic of RCP composers suing each other for lifting thematic material. Some thematic ideas - notably the cyclical chord progressions that Zimmer is so fond of - are so ubiquitous to scores by the composers working from Zimmer's Santa Monica facility that they instantly illuminate the employment history of those who utilize them ${ }^{13}$ (video excerpt 3 ).

12 The music volume for each excerpt has been artificially increased.

13 Two common chord progressions used by Zimmer and his collaborators are included in this clip. The first has four examples and is the chord progression made particularly recognizable by the Inception cue "Time": Am / Em / G / D / Am / CMaj7 / G / D. This chord progression works well in cycles because the tonic remains ambiguous. The second chord progression, represented by three examples, is a common pop progression: i-bVI-III-bVII, or Dm / Bb/ F / C in the King Arthur and At World's End examples. 


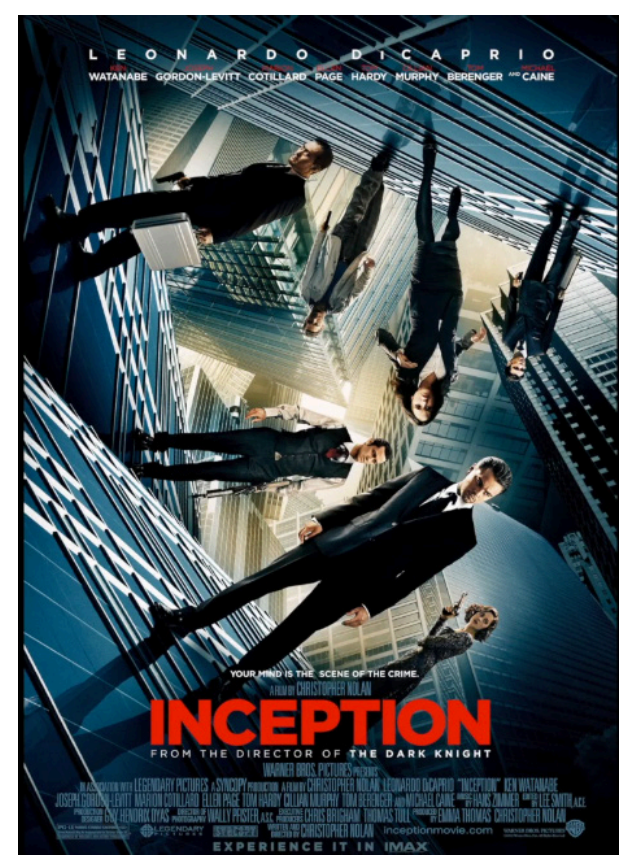

Video Excerpt 3 : Hans Zimmer, "Time,” Inception, 2010, CD Reprise 09362496503; Hans Zimmer, "Solomon," 12 Years A Slave, 2013, CD Columbia/Sony Classical 88843008572; Henry Jackman, "Safe Now," Captain Phillips, 2013, CD Varèse Sarabande 067226; Rupert Gregson-Williams, "Duck Shoot," The Crown, 2016, CD Sony Classical 88985383572; Hans Zimmer, "Woad to Ruin," King Arthur, 2004, CD Warner Brothers 5046746642; Hans Zimmer, "One Day," Pirates of the Caribbean: At World's End, 2007, CD Walt Disney D-000037102; Rupert Gregson-Williams, "We Are All To Blame," Wonder Woman, 2017, CD WaterTower Music 39897.

Zimmer is, of course, certainly not the only composer to re-use material between scores - one must simply reflect upon the career of James Horner, particularly the "Danger Theme," to recognize that fact ${ }^{14}$-and I have little interest in indicting him for that practice (though I do find material reused between scores ostensibly by different composers to be problematic). There are essentially no composers capable of being totally original from score to score, especially when writing under the pressure of a hard deadline. As Lehman notes, Zimmer is almost certainly harmed in this aspect by his own style:

Allegations of unoriginality are made easier by the fact that Zimmer's musical vocabulary is limited and mostly quite conventional; he seemingly has little interest in harmony outside the tonal Common Practice, and certainly not with genuine avant-garde or modernist idioms. His cues are often thickly scored, but without being finely wrought contrapuntally. Countermelodies are fleeting, genuine independence of lines is rare (but not nonexistent), and often the middle range of the orchestra is treated purely as a vehicle for static sustained chord tones (if it is filled at all) (Lehman 2016, p. 46).

14 See my video essay on "The Danger Theme" and self-plagiarism in film music on Youtube: www.youtube.com/watch?v=DfzqxCshIaY. Video uploaded 7 September 2016. Accessed 20 April 2018. 
Regardless, many of these questions of authorship are a direct byproduct of Zimmer's preferred collaborative environment, and in many ways, seem exaggerated by it. Many academics struggle with how to acknowledge and treat this issue, particularly in relation to Zimmer, because he consistently challenges intellectual and cultural notions of what it means to be a composer - the traditional definitions assigned to the members of the music department don't always fit particularly well when considering projects produced by RCP. Many academics simply decline to reference the existence of additional music credits at all. Tillman's analysis of Zimmer's and Lisa Gerrard's score for Gladiator (Scott, 2000), for example, does not mention the contributions of Klaus Badelt, who helped write several cues and received an additional music credit for doing so (Tillman 2016). As Paulus and Nijstad note, academic literature on creativity is negatively tilted towards group endeavors, the assumption being that "groups may inhibit intellectual activity or optimal performance" (Paulus and Nijstad 2013). This issue has only been exacerbated by progress in technologies that have allowed other members of the music team to secure a greater stake in the creative process, a phenomenon Parker and Davis have described in their discussion of the contemporary recording engineer; rather than being simply responsible for the recording of instruments, modern engineers are often tasked with designing and manipulating sounds electronically, serving as mediators between musical artists and technology (Parker and Davis 2013). Similar changes in technology have led to significantly expanded roles in film music for music editors, who, due to developments in digital editing software, may be tasked with making hundreds or thousands of edits to a film score independently from the composer (Kmet 2018).

A common response is to simply criticize Zimmer outright for these practices, an unproductive choice that places lofty and outmoded ideals over any common-sense discussion of the industry; it's easy to forget that film composers are less artists and more artisans, plying their trade in deference to others. Unfortunately, these issues are unlikely to resolve themselves; Zimmer remains prolific with no signs of slowing down, and his collaborative model has only seemed to gain in popularity among those working in the industry today. While it seems unlikely that similar studios will ever entirely supplant more individualized modes of composition, the realities of the industry's business practices mean that such collaborative environments for composers are here to stay. Of course, Zimmer and his collaborative approach should not be shielded from any and all criticism. There are certainly legitimate critiques to be made, particularly aesthetically, both in the repetitive nature of his personal style and the blandness of having so much of today's market dominated by the RCP sonic style. However, I question the usefulness of sweeping attacks on the collaborative environments that have become the method du jour for much of film scoring. Researchers - and enthusiasts - must be willing to adjust their expectations to meet this new collaborative reality, particularly in how we conceptualize the role of the film composer in general, because in Zimmer's world individual achievement is less important than collective success. 


\section{BIBLIOGRAPHY}

Burlingame, Jon (2014), "Factory as Finishing School," Variety, vol. 323, nº 14 (6 May), p. 78.

Cassidy, Kevin (2011), "What WME's Big Score Means," Hollywood Reporter, vol. 417 (26 August), p. 30.

Cassidy, Kevin (2008), "Hans-on Approach," Hollywood Reporter, vol. 407 (13 November), p. S10-S16.

Clarke, Jocelyn (2009), "Hearing a Bigger Picture," Irish Times (18 May), p. 16.

Clemmensen, Christian (2011), "Pirates of the Caribbean. The Curse of the Black Pearl," filmtracks.com (20 July), www.filmtracks.com/titles/pirates caribbean.html, accessed 20 April 2018.

Goldwasser, Dan (2006), "Interview. Breaking the Rules with Hans Zimmer," Soundtrack.Net (26 September), www.soundtrack.net/content/article/?id=205, accessed 20 April 2018.

Hurwitz, Matt (2007), "Hans Zimmer's Scoring Collective", Mix Online (1 September), www.mixonline. com/sfp/hans-zimmers-scoring-collective-369180, accessed 20 April 2018.

Kmet, Nicholas (2018), "Orchestration Transformation: Examining Differences in the Instrumental and Thematic Colour Palettes of the Star Wars Trilogies," in Emilio Audissino (dir.), John Williams: Music for Films, Television, and the Concert Stage, Turnhout, Brepols Publishers, p. 209-228.

Kofsky, Steven (2016), "14 $4^{\text {th }}$ Street Music: About Us," www.14thstreetmusic.com/about-us, accessed 20 April 2018.

Lehman, Frank (2016), "Manufacturing the Epic Score: Hans Zimmer and the Sounds of Significance," in Stephen C. Meyer (dir.), Music in Epic Film: Listening to Spectacle, New York, Routledge, p. 41-69.

Levine, Michael A. (2013), "Why Hans Zimmer Got the Job You Wanted (And You Didn't)," Behind the Audio (12 July), behindtheaudio.com/2013/07/hans-zimmer, accessed 20 April 2018.

Lobenfeld, Claire (2017), "Blade Runner 2049. How Hans Zimmer and Benjamin Wallfisch Followed Up the Most Influential Sci-Fi Score of All Time," FACT(20 October), www.factmag.com/2017/10/20/ hans-zimmer-wallfisch-blade-runner-2049-interview, accessed 20 April 2018.

Macaulay, Sean (2013), "Scores that Make Good Movies Great," The Daily Telegraph (5 September), p. 24.

Parker, Steven and Robert Davis (2013), "More than microphoning. Capturing the role of the recording engineer from the 1980s to the 1990s," Popular Music History, vol. 8, n 1, p. 49.

Paulus, Paul B. and Bernard Nijstad (2003), Group Creativity. Innovation through Collaboration. Oxford, Oxford University Press, p. 4.

Reyland, Nicholas (2015), "Corporate Classicism and the Metaphysical Style," Music, Sound, and the Moving Image, vol. 9, n 2 (Autumn), p. 115-130.

Schweiger, Daniel (2011), "Audio. On the Score with Hans Zimmer," Film Music Magazine (16 May), www.filmmusicmag.com/?p=7890, accessed 20 April 2018.

Tillman, Joakim (2016), "Topoi and Intertextuality: Narrative Function in Hans Zimmer's and Lisa Gerrard's Music to Gladiator," in Stephen C. Meyer (dir.), Music in Epic Film: Listening to Spectacle, New York, Routledge, p. 71-97.

Wilson, Sean (2017), “John Powell Interview. Scoring Bourne, Hans Zimmer, Face/Off and More," Den of Geek! (6 July).

Zanelli, Geoff (2017), "Pirates of the Caribbean: The Curse of the Black Pearl (Additional Music)," geoffzanelli.com/projects/pirates-caribbean-curse-black-pearl, accessed 20 April 2018.

\section{FILMOGRAPHY}

Badham, John ([1994] 2010), Drop Zone, Paramount Pictures, Blu-ray, Lionsgate Films, 27057.

Bay, Michael ([1996] 2008), The Rock, Buena Vista Pictures, Blu-ray, 53692.

Bay, Michael ([2007] 2017), Transformers, DreamWorks Pictures, Blu-ray, Paramount Pictures, 13124. 
Berlowitz, Vanessa et al. ([2016] 2017), Planet Earth II, BBC, Blu-ray, 1000635160.

Bigelow, Kathryn ([2002] 2010), K-19: The Widowmaker, Paramount Pictures, Blu-ray, 14294.

Brownlow, Mark and James Honeyborne ([2017] 2018), Blue Planet II, BBC, Blu-ray.

Fuqua, Antoine ([2004] 2007), King Arthur, Buena Vista Pictures, Blu-ray.

Greengrass, Paul ([2013] 2014), Captain Phillips, Columbia Pictures, Blu-ray, Sony Pictures, 41781.

Jenkins, Patty ([2017] 2017), Wonder Woman, Warner Bros. Pictures, Blu-ray, 2000138861.

Nolan, Christopher ([2005] 2008), Batman Begins, Warner Bros. Pictures, Blu-ray, 2000080062.

Nolan, Christopher ([2008] 2008), The Dark Knight, Warner Bros. Pictures, Blu-ray, 2000080063.

Nolan, Christopher ([2010] 2015), Inception, Warner Bros. Pictures, Blu-ray, 2000041982.

McQueen, Steve ([2013] 2014), 12 Years A Slave, Fox Searchlight Pictures, Blu-ray, $20^{\text {th }}$ Century Fox, 2288101.

Morgan, Peter ([2016] 2017), The Crown (Season 1), Netflix, Blu-ray, Sony Pictures.

Scott, Ridley ([2000] 2017), Gladiator, DreamWorks Pictures, Blu-ray, Paramount Pictures, 11111019853.

Scott, Ridley ([2001] 2006), Black Hawk Down, Columbia Pictures, Blu-ray, Sony Pictures, 15023.

Skolimowski, Jerzy ([1984] 1999), Success is the Best Revenge, Gaumont, VHS, Inermedia Video Pro.

Verbinski, Gore ([2003] 2011), Pirates of the Caribbean: The Curse of the Black Pearl, Walt Disney Pictures, Blu-ray, 8018663.

Verbinski, Gore ([2006] 2011), Pirates of the Caribbean: Dead Man's Chest, Walt Disney Pictures, Blu-ray, 8018661.

Verbinski, Gore ([2007] 2011), Pirates of the Caribbean: At World's End, Walt Disney Pictures, 8018654

Verbinski, Gore ([2011] 2017), Rango, Paramount Pictures, Blu-ray.

Villeneuve, Denis ([2017] 2018), Blade Runner 2049, Warner Bros. Pictures, Blu-ray, 2000139201.

Wells, Simon ([2002] 2002), The Time Machine, DreamWorks Pictures, DVD, 89972.

Zwick, Edward ([2003] 2006), The Last Samurai, Warner Bros. Pictures, Blu-ray, 110809. 